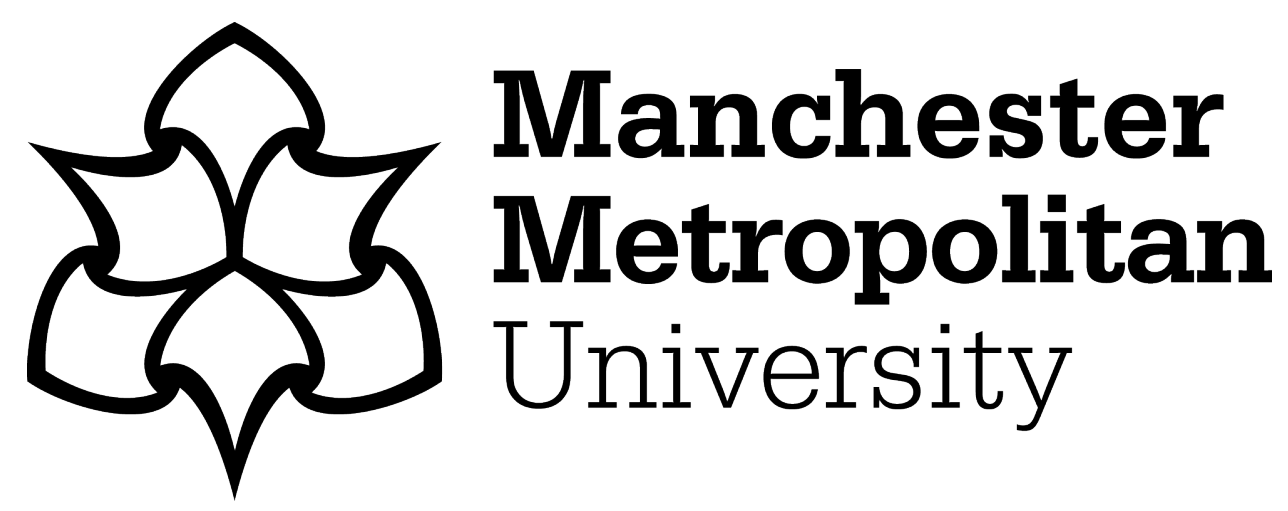

Bennett, Julia (2018) Narrating family histories: negotiating identity and belonging through tropes of nostalgia and authenticity. Current Sociology, 66 (3). pp. 449-465. ISSN 0011-3921

Downloaded from: https://e-space.mmu.ac.uk/567004/

Version: Accepted Version

Publisher: SAGE Publications

DOI: https://doi.org/10.1177/0011392115578984

Please cite the published version 


\title{
Narrating family histories: Negotiating identity and belonging through tropes of nostalgia and authenticity
}

\begin{abstract}
Studying change is at the heart of any investigation into social life, whilst continuity is seen as central to a stable identity over time. Change is an unsettling, but inevitable, part of everyday life; continuity speaks of repetition over time, unity and the comfort of belonging. This paper examines how themes of nostalgia and authenticity are evoked in telling family histories in order to negotiate change and create a continuous story of belonging. Three family histories demonstrate how material objects, places and claims of family resemblances are used to create both authentic identities and authentic selves belonging to the wider community. Where there is a break in the family story and the 'world of restorable reach' is no longer available nostalgia creeps in to replace personal stories with communal ones. Through using both nostalgia, to inform a sense of loss and sometimes a shared past, and authenticity, to create a sense of continuity within an overall arc of change, this paper shows how family histories can work to maintain identities over time, retaining a sense of ontological security and belonging in place.
\end{abstract}




\section{Keywords}

Family history; authenticity; nostalgia; identity; belonging

\section{Introduction}

Change is inevitable: living things grow old and die; inanimate objects decay through time. Society also changes. Therefore change is at the heart of any investigation into social life (May, 2013; Strathern, 1992). However, whilst investigating change, an analysis of continuity, by which change in society must be measured, may be overlooked despite its importance for identity creation. These twin ideas - change and continuity - exist in tension with one another (Strathern, 1992, p. 1); neither can be recognised without the confirmatory presence of the dichotomous other. This article examines how people negotiate the tensions between change and continuity in their lives and the societies they inhabit through claims of authenticity and tropes of nostalgia in autobiographical narratives and family histories. 
Basu $(2004,2007)$, Nash $(2004,2005)$, Fortier $(1999,2000)$, and more recently Dragojlovic (2014), Green (2013) and Zerubavel (2012) amongst others, have written of the ways in which claims to authenticity are made through particular places and their part in family histories. This paper revisits some of these concerns but, by using the narratives of those who have remained 'in place' rather than migrants, locates authentic identities within wider concerns of social change (Farrugia et al, 2014). Understanding the effects of social change is a central interest of sociology (May, 2013: 5-6). The testimonies used here are from people who are connected to the place through life-long residency. In addition to the kind of imaginary connections to the past of the place that Basu (2007), Nash (2003) and Dragojlovic (2014), write of in respect of a sense of loss and victimhood mitigated by diasporic 'homecomings', an on-going, material connection to the place creates a firm basis for evaluating change. Examining the taken-for-granted changes presented in family narratives shows the way in which the security of belonging can overcome instability caused by change. This article will investigate how an identity as someone of the place is created through stories of family connections over time and how these stories account for change in the place and community they are a part of. 
It is change, rather than continuity, which is more difficult to come to terms with for many people, as it can lead to a loss of ontological security (Back, 2009; Giddens, 1991; Savage, 2008). A feeling of belonging may mitigate this loss (Bennett, 2012; May, 2013) Belonging can be related to a sense of continuity, as well as a sense of self making narratives of belonging a window onto the impact of change on self and society (May, 2013). Belonging anchors one within a group for a period of time, creating continuity over time and mutual recognition between self and others (Hage, 2003). However, the past, as it is always viewed from a distance, is often seen as relatively fixed and stable compared to the present (May, 2013). This can give the impression of an ontological security in the past that perhaps was not seen to exist at the time (Back, 2009; Bell \& Newby, 1971). If we accept that we create the social world intersubjectively through shared understandings (Crossley, 1996; Schutz, 1962) then society, which often appears relatively static, is seen to be in constant flux, re-created through collective meanings and actions, Schutz's (1962) 'stock of knowledge'. Actors in the world create it afresh with each action; everyday life is repetitive but never exactly the same (Ingold, 1993). Schutz (1962) used the idea of 'worlds of reach' whereby the present, past and future share a stock of knowledge and conceptualise sameness over time. These help to maintain an appearance of continuity until, perhaps, a 
faster rate or a greater number of changes, together with the benefit of hindsight, causes a perception of great change which sometimes leads to feelings of nostalgia (Back, 2009; Blokland, 2001; Davis, 1979; Lowenthal, 1989; Savage, 2008; Savage et al., 2005). On the other hand, the gradual changes over an individual life are constantly smoothed over through the creation of a cohesive life narrative (Green, 2013; Lawler, 2008). This is seen as the basis for a feeling of 'ontological security' (Giddens, 1991), which raises the question of how individual life stories are reconciled with family and generational tropes. The creation of a cohesive narrative over multiple generations of a family is one way of linking an authentically cohesive self to an equally authentic, but also different, past (Bottero, 2012; Déchaux, 2002; Kramer, 2011; Lambert, 1996).

Family histories contribute to understanding change by linking one's own environment with a wider past (Scodari, 2013; Zerubavel, 2012). Tropes of both nostalgia and authenticity playing off each other create a tension between change and continuity (Strathern 1992). As relational constructs, narratives can bring existing relationships into relief (Hubble and Tew, 2013). We all have ancestors but we have personal memories of one or two, perhaps three generations before us, at most. Family stories either passed on or discovered through research, help to 
recreate unknown ancestors in the present. Schutz (1962) describes this reaching back into the past as 'the world of restorable reach'. This world contains shared cultural memories and is used to make sense of changes in the present (Rose, 1988: 166). It is through connections to the shared stock of knowledge that a sense of continuity and belonging are forged. Where the worlds of restorable and actual reach are irreconcilable, the authenticity of the taken-for-granted meanings inherent in the shared worlds is lost (Rose, 1988: 166). Where there is a loss of connection with the past then looking back can become nostalgic: changes which leave no trace in the present create a rupture between past and present (Bennett; 2014b; Dragojlovic, 2014). On the other hand, change which leaves a material trace can forge authentic inalienable connections between past and present. As Ingold puts it 'the landscape is constituted as an enduring record of - and testimony to - the lives and works of past generations who have dwelt within it, and in so doing, have left there something of themselves' (1993: 152). In '[leaving] there something of themselves' previous inhabitants lay the foundations for an authentic connection from the future as those with diasporic ancestry have discovered (Basu, 2004, 2007; Dragojlovic, 2014; Nash, 2003, 2005). However, imagining the past in which these ancestors lived to be somehow conducive to a way of life, more real or authentic in itself, is a nostalgic framing of the past. 
Nostalgia is generally used to describe a fond looking back at a past that no longer exists, but it is a slippery concept (Chase and Shaw, 1989). There is a certain trope of nostalgia that may be present when older people in particular feel a sense of dislocation from their past (Blokland, 2001; Savage et al., 2005). Nostalgia is characterised by a longing for something now gone, which may be something as vague as a 'way of life' (Wright, 1985). Bemoaning the loss of something is a way of expressing feelings of dislocation caused by changes to one's environment (Back, 2009). Belonging through the continuity of a community can be a counterbalance to nostalgia (Blokland, 2001; Déchaux, 2002; Green, 2013) and is also implicated in discourses around authenticity (Dicks, 2008; Jones, 2010). An 'authentic' object or story is the 'original' or 'real' one also embodying continuity over time. As Déchaux, (2002: 232) puts it 'I'm someone because I come from somewhere' and 'I proceed out of others, I'm not alone'. Both nostalgia and authenticity figure strongly in family narratives and both tie together people and places through time (Back, 2009; Basu, 2004, 2007; Green, 2013; Scodari, 2013). However, there is currently little analysis of how these concepts are used to create continuity in a sense of belonging. 
The next section examines the notions of nostalgia and authenticity as they will be used here. This is followed by a discussion of narrative and how narratives can be used to structure and produce identities. A brief overview of the research the particular narratives used here are taken from precedes an analysis of the way the family histories illustrate how nostalgia and authenticity are negotiated in narratives of belonging.

\section{Nostalgia and authenticity}

Nostalgia was originally used to describe homesickness but has come to mean a looking back to a lost past - usually one that was, at least implicitly, 'better' than the present (Davis, 1979), in a generic, unspecified way. Nostalgic are a specific genre of oral history narrative, using particular forms and language (Thompson, 2000). In using this particular genre people are responding to an understanding of

the way histories are told (Chamberlain \& Thompson, 1998: 10). Asking an older person about their past is likely to imply a question about change and one way to describe change is to differentiate the past from the present. This can lead to nostalgic tropes in life story-telling without necessarily the element of a feeling of loss that nostalgia implies (Robertson et al., 2008). 
Les Back (2009: 2-3) demonstrates the fickle nature of the nostalgia shown by market traders in south London: the fishmonger he spoke to repeatedly spoke of London being 'different' now and described London as 'finished' three times. And yet, his family's 100 year old business is still going and his son is 'keeping on the tradition'. As Back (2009: 3) points out, nostalgia of this sort is closely related to ideas of community which is here seen as having changed considerably. Savage et al (2005: 33) found similar stories of loss and difference amongst residents of Cheadle in Manchester. Both narratives hark back to an original community where 'people knew each other' (Back, 2009: 2). As Savage et al (2005: 33) explain this idea of an original community means that the sense of place, for these people, is 'driven by time'. Back's respondent refers to his mother to give a sense of generational time. The shared focus on the continuation of families living in the same place for multiple generations creates a sense of safety through continuity, or ontological security, which has now been lost through the reduction in the size of the older communities. Although there is no doubt that the people expressing these nostalgic feelings for a lost past are describing a genuine sense of loss, many people will be aware of the nostalgic genre as a way of distinguishing the past from the present in telling their histories and are perhaps 
likely to draw upon this when asked about the past (Chamberlain and Thompson, 1998: 10). Even young people can evoke the language of nostalgia when describing themselves as embedded in a particular place-community (Farrugia et al, 2014: 1159).

Nostalgia refers to a past which is over, but whether or not this is construed as a 'loss' varies. For Fortier's (1999) Italian migrant community and for Dragojlovic's (2014) Indies community there is both nostalgia for the past of the diasporic community and for the 'Arcadian home' (Dragojlovic, 2014: 484). Blokland (2001: 278), in looking at the changes taking place in a formerly industrial area of Rotterdam, shows how memories can be, or seem to be, nostalgic but still position the present as a time and place which is 'more comfortable'. Robertson et al (2008:62) also see older peoples' memories of the past in Stirling as possibly containing elements of nostalgia, but without an overly pessimistic connotation. That is, the past is not seen as necessarily fostering a greater community spirit than the present. These last two examples in particular focus on community memories and changes to communities. The respondents were all keen to create an identity for themselves as authentic members of this community in the past, as did Back's (2009) market traders. Back (2009), Green 
(2014), Savage et al (2005), Robertson et al (2008), Fortier (1999) and Blokland $(2001 ; 2003)$ all show how individuals place themselves in an explicit moral relationship to a past community through eliciting memories which are distant enough to create a distinct sense of 'otherness' with the present. 'We' then become the group who can 'remember', and 'they' are those who cannot (Blokland, 2001). Being an authentic member of the community is, as Back (2009) says, 'a moral project'. Only the authentic 'we' can draw on the nostalgic tropes of memories of 'our' past.

Authenticity is not a completely separate concept but entwines with nostalgia to create a sense of continuity through a direct link back to origins. What Patrick Wright (1985: 217) calls 'cultural authenticity' is measured in terms of continuity in contrast to the nostalgia around change. Changes in the uses of buildings and other aspects of the material place are a focus of the nostalgic conversations Blokland (2001) writes of and a common form of re-membering a place in the past (Bonnett \& Alexander, 2012). However, authenticity creates a greater sense of 'truth' than nostalgia (Dicks, 2008) and can play a key role in creating a sense of belonging to a community (Jones, 2010). In describing inalienable relationships to a community over time, Jones (2010) argues that it is not the originality of the 
communal site itself which creates an aura of authenticity but the relationships which attach to the place over time. Thus the Pictish stone unearthed at Hilton of Cadboll had inalienable connections to the community throughout the time it had existed, even when it was buried in the ground (Jones, 2010: 93-95). The originality of the stone allowed people to 'negotiate their own authenticity' ( $p$. 194) as members of the community through the connections they could draw with it through their own family stories. The stone sanctioned authentic identities in the present, through the links to the past embodied within the stone; authenticity thus embodies continuity through time. Whereas nostalgia positions the present in opposition to the past, authenticity brings past and present together through ongoing inalienable relationships often embedded within objects and places (FavartJardon, 2002; Jones and Yarrow, 2013). Authenticity therefore serves to minimise the loss of ontological security which change can precipitate and instead promote a sense of belonging (Jones, 2010). In family history research material authenticity may be articulated through DNA (Kramer, 2015; Scodari, 2013; Zerubavel, 2012). This new, technologised genetic genealogy 'feeds the longing for the past that is evidenced in the heritage boom' (Kramer, 2015: 80), thus bolstering nostalgia whilst simultaneously creating authentic belongings to ancestral homelands and ancient communities (Zerubavel, 2012). Authenticity 
creates an anchoring sense of identity, an attachment to something 'real' or 'natural' in the past; nostalgia, in contrast, creates an oppositional 'them and us' sense of identity. 'We' are the original inhabitants of this place and value it as it was, in a past which we have lost or are losing, whereas 'they' want it to change and become modern (Bennett, 2014b; Back, 2009; Blokland, 2001; Savage et al., 2005; Wright, 1985). Authenticity unites a community through time and can thus create a continuous family or community identity. Nostalgia, in contrast, posits a rift between the past and the present, often implying that the present community is 'new', 'unnatural' and 'inauthentic'. However this distinction is often not clear cut and a single narrative can veer between these two senses of the past (Dicks, 2008).

\section{Narratives as identity creation}

In using family histories rather than individual biographical narratives, relationships between family members, and others, through time can be dissected (Bertaux \& Delcroix, 2000). These are both intersubjective relationships and socio-structural relations. Family in this sense extends beyond the nuclear family and even beyond the known, current family into ancestry and possible future descendants. Family histories can therefore throw light on both generic aspects of 
family life such as gender roles or bringing up children (Green, 2014; Scodari, 2013), and on more abstract social concepts such as connections through time, authenticity and nostalgia (Kramer, 2015; Zerubavel, 2012).

Steph Lawler (2008) suggests that far from being straight forward, identities are created partly through memories and experiences but also in the way these are interpreted. The family history case studies here will illustrate this point. Lawler (2008) draws on Paul Ricoeur's work in defining a narrative as having characters, action and plot. Where these 'characters' are merely names on census data the family history researchers interviewed here have often worked to make them into distinctive characters and they are spoken of as if they are personally known to the researcher. Action, movement through time, is implicit in historical research but it is also 'spiced up' through stories of drunks, illegitimate children, unfaithful wives and untimely deaths. The plot, which brings together the different events in the stories, results in the researcher's own story - how he/she came to be who he/she is (Zerubavel, 2012). All of these elements of the story - characters, action and plot - are shaped by the storyteller to seem as authentic as possible. That is, they are positioned as if of their time and made to fit into the researcher's own understanding of the past (Bottero, 2012). 
The narratives of self-identity begin with forebears (Lawler, 2008: 42) and it is through the family that '... social values and aspirations ... taken-for-granted ways of belonging' are passed on (Bertaux \& Thompson, 2005: 1). The self can be constructed through referring to family 'myths, figures, events and the like' (Déchaux, 2002: 231) which pre-exist and are independent of the self and can thus be seen as authentic. But whilst a narrative understanding of these family histories is interesting as the 'raw material of social history' (Bertaux \& Thompson, 2005: 14), a biography is more than a recreation of past events in the present. A biography is, as with all histories, necessarily teleological: its purpose is to explain how things came to be as they are now, today, in the present moment (Anderson, 2006). And this explanation will, essentially, constitute the identity of the person, family or community whose biography it is (Taylor and Littleton, 2006). It is this combination of bringing the past into the present through the ‘creative and imaginative memory practice' (Kramer, 2011: 392) of telling a family story, and the part this story plays in the creation of a social identity, that make family narratives or histories particularly useful in examining how people negotiate change through time. 


\section{The Research}

The family histories used here are taken from a wider project looking at belonging in place (Bennett, 2012) and a fuller elucidation of the methodology can be found in Bennett (2014a). All the families who took part live in Wigan, a former coal and cotton town in Lancashire, situated between Manchester and Liverpool in the North West of England. The mining and cotton industries, now gone, have left a strong industrial heritage in the town.

The biographical narratives were taken at interviews with one or more family members present. Interviewees were asked to tell their life story and those of ancestors, where this was known. Some respondents then went on to complete photo-diaries over the course of a week and take part in a subsequent interview to discuss the diaries. This data is not used in the following discussion. In this article I am drawing on the narratives of three individuals who had carried out a considerable amount of family history research before they were interviewed and I approached them on the basis of focussing the interview on their family history research, rather than their own individual life stories. There was no mention in the interviews of nostalgia or authenticity - these concepts arose from the data 
analysis. These 'family histories' include stories that have been passed down, individual memories, for example from childhood, 'facts' discerned from census data and places that are meaningful to the family - for example houses and work places. The incorporation of material spaces into the narrative expands the straightforward biographical framing of the family history. For these people who have delved into their family background in detail it seems to be a source of pride and an important part of their identity (Kramer, 2011). Other participants in the research also created their identities through their families but this tended to be limited to their parents. The interest here is in those who have fashioned identities based largely on an 'imagined family' of people they have not met yet who lived in the places they know. The narratives were analysed thematically and using the narrative, the way the story was told, as the object of analysis (Flick, 2002; Taylor and Littleton, 2006), an approach which helps to draw out the connections between biography, history and society. Narratives exist within an historical and geographical context and can therefore tell us something about life in that time and place (Bruner, 1991: 3; Hubble and Tew, 2013). They thus 'create the possibility of history beyond the personal' (Richardson, 1990: 127) allowing the cultural history of the community to be analysed (Flick, 2002: 202). 
Barbara and Antony were the only members of their families to be interviewed; Ian's sister and some of her descendants were also interviewed. Barbara would probably describe herself as middle, or lower middle, class. Ian is middle class whereas Antony was proud to describe himself as working class. They told stories that had clearly been told many times before and, in Barbara's case, written down. People often produced photographs as material evidence for their stories. Ian came to the interview armed with a family tree which took up most of the space on the large table in the conference room at the university where we met. Shared symbolic constructs, such as the idea of 'generation' and family trees, are useful devices for retelling the past in the present (Strathern, 1992: 28), with the lines connecting siblings and generations symbolising continuity. In all the examples used here respondents repeatedly linked their own lives to those of their, often unknown, ancestors. They were all keen to highlight either family traits or how they had transcended the stock family traits to improve the family's social position (see also Green, 2013). These particular respondents all had a wider interest in local history as well, which enabled them to frame their stories within the context of the history of Wigan (Bottero, 2012).

\section{Three Family Histories}


Carol Smart (2007: 106) draws attention to the two dominant accounts of personal biographies: the roots and heritage trope, which tends to reify the past, and the choice thesis, whereby we make our own identities as individuals. Smart goes on to explain that "neither of these versions captures the complexity and layers of the process of biography building' (2007: 106), a point supported by the family histories detailed below. The idea of roots and heritage can evoke a sense of authenticity with the reified past providing a sense of identity (Déchaux, 2002; Green, 2013) and therefore ontological security. The 'choice' narrative gives the individual freedom to choose from an array of 'values, motifs and practices' (Smart, 2007: 106). Déchaux (2002: 232) also sees the individual as 'in no way obligated' to accept the narrative bequeathed to them, whilst retaining the security of a place in the order of the family. It is perhaps more useful here to view the roots and heritage trope as evoking authenticity when combined with freedom of choice, but when roots and heritage are no longer available to the individual (change has reached a tipping point and the world of restorable reach has moved out of reach (Rose, 1988)) then nostalgia, with its evocation of a sense of loss, comes into play (Dicks, 2008; Dragojlovic, 2014). The different uses to which Barbara, Antony and Ian put their family histories show how these strategies are 
drawn on at different times within their narratives to create a particular individual and family identity in the present, taking account of social change within Wigan and national and global arenas but also emphasising continuities. As Green (2013: 398) explains 'history largely presents the past in terms of broad socioeconomic and discursive structures and patterns of change within which ordinary people have little room for manoeuvre' so it is through family stories that 'a sense of continuity' is created.

After a brief introduction to the three protagonists a discussion of their narratives shows how their own identities and sense of belonging are constituted through an understanding of their ancestors' lives within this place.

\section{Barbara}

Barbara (75) is secretary to a local history society and a member of other local groups. She has compiled a family history but many of the people she included in her narrative were known to her personally. Her grandfather, who died before she was born, was spoken of in such familiar terms that it seemed that she had also known him when she was a child. Many of Barbara's family stories are committed 
to paper through her writing classes and are thus told as familiar tales, rather than being recounted afresh with each telling.

\section{Antony}

Antony is 25, works part-time and campaigns to save Wigan's historical buildings. Antony constructs his identity as a local inductively, beginning with his surname which 'leads inexorably from the earliest imagined beginnings to the present' (Lambert, 1996). Antony's surname is 'a Lancastrian name, it's very rare to find one elsewhere unless they've emigrated from Lancashire' (Antony's interview). This enables Antony to lay a strong claim to an authentic local identity (Taylor \& Littleton, 2006: 25). However, in contrast to Barbara, Antony does not have a continuous trajectory from a respectable working class past to an equally ordinary present.

\section{Ian}

Ian is 62 , a retired teacher and was the first in his family to attend university. His family have lived in Wigan since at least 1720. Ian embraces a topical narrative of social mobility. He is also a keen local historian. 


\section{Family and identity}

Knowledge of family history can play a crucial role in creating identities in the present (Basu, 2007; Dragojlovic, 2014; Green, 2013; Kramer, 2011; 2015; Zerubavel, 2012). Each of the family stories narrated here tell of particular pasts which allow the narrators to locate themselves within a narrative of continuity, whilst also creating a 'dialogue' (Green, 2013: 398) between the generations.

Barbara began her life story with the tale of her grandfather who died in a tragic accident. He is, for Barbara, the founder of the dynasty of which she is now the matriarch (Lambert, 1996). He was a master tradesman and a member of the local Voluntary Ambulance brigade and thus 'very, very highly respected'. Barbara produced a framed photograph of her grandfather in his Ambulance Brigade uniform to authenticate her story. Each of the three respondents showed me or talked about the tangible aspects of their ancestors' legacies which seemed designed to help make their stories authentic (Favart-Jardon, 2002). When it came to starting work Barbara joined the company where her father worked and her grandfather had worked previously: 'and I went there straight from school, so 
there was three generations of us who had gone to the same firm'. These tangible connections to previous generations allow Barbara to present herself, somewhat unusually for a woman, as the natural (and authentic) heir of her father and grandfather (Favart-Jardon, 2002; Green, 2013).

Antony's identity as respectable working class is based on his grandfather and great-grandfather who were mill engineers, skipping over his father who suffered unemployment during the industry closures of the late 1970s. It may be this disjuncture in the family narrative that causes a sense of nostalgia to creep into Antony's story:

... but I'm of the belief that if the textile industry were still going I'd be in there working as well because I can just feel, you know I just, I can feel it, that's where I belong you know ... so definitely if the industry was still going I'd be in there along with me forefathers ...

(Antony's interview) 
Throughout his interview Antony frequently referred to previous generations as 'we' and in this extract he talks about being in the mill 'along with' his forebears. Antony demonstrates a strong identification with his antecedents, indeed one could say that 'home' for Antony is in the past (Basu, 2007: 7). Whilst the notion of 'getting to know' ancestors is given elsewhere as a reason for conducting family history research (Kramer, 2011; Lambert, 1996), Antony is going further in creating an imagined community of the past in the present (Basu, 2007: 33). His narrative encompasses a sense of loss, both in his personal family history and in his interpretation of local history. Whilst remaining in the same geographical location as his ancestors, Antony's depiction of his father's generation as 'lost' represents a distance or separation in time from his ancestors similar to the geographic distance found in Basu's (2007) and Dragojlovic's (2014) research. Antony also needs to travel to reconnect with ancestors, in his case back in time through his imagination:

I tried to sort of fantasise all these thousands of workers around working, all the steam and the chimneys bellowing and all that ...

(Antony's interview) 
There is a lack of continuity in the family narrative for Antony as he was not, unlike Green's (2013) participants, brought up on these stories, which leads to a nostalgic yearning for a past he did not experience (Davis, 1979).

Although mining was the common background across all the generations in Ian's family, until the present, there were also lots of stories of those who had done 'better' for themselves, such as 'Henry' who 'took over the pub' and others who became coal dealers and insurance agents which Ian classified as more middle class jobs. Perhaps unusually he clearly attempts to distinguish the social positions of his forebears (Bottero, 2012: 59), as, for him, this is a crucial aspect of his story. Ian links his own identity most closely to the enterprising strand of the family. He has followed in this tradition in that he has been to university and he is clearly pleased that his children have both been to university. In finding ancestors who also tried to better themselves, Ian is able to authenticate his identity claim as the true descendant of these ancestors (Green, 2013). Ian's family history research has allowed him to explore his sense of identity, founded upon a rootedness in place (Kramer, 2011; 392) which he has used as a starting point to continue the socially mobile trajectory he found in some of his ancestors. 
Barbara and Ian's stories connect them to their roots helping to provide them with an identity as a person of this place (Déchaux, 2002; Green, 2013) and therefore a sense of belonging (Back, 2009; Blokland, 2001; Kramer, 2011). Antony, on the other hand, has a break in his connection to his forebears and thus evokes a sense of loss and nostalgia, similar to those geographically distant (Basu, 2007;

Dragojlovic, 2014). However, Antony does connect to a wider sense of place, as a Lancastrian rather than a Wiganer, through his surname. This is an authentic connection based on birth in a similar way to genetic connections (Kramer, 2015; Zerubavel, 2012). His name is something Antony has had since birth and links him to a wider, largely unknown, 'family'.

\section{Connections to place}

Each of these narrators was keen to demonstrate material connections to the place where they can trace their ancestry back to the eighteenth century, in the cases of Ian and Antony. 
For Barbara the most important tangible legacy left to her by her antecedents was the house she grew up in:

But as I said I was born down the road in a house that was built in 1911, my grandfather built that with the gentleman next door so I lived in that house, my dad lived in that house and my grandfather lived in that house, so that was three generations of us living, lived in the same house (Barbara's interview)

There is a clear sense of continuity between the three generations through the inalienable connections present in the house. Growing up in the house her grandfather built gave Barbara an authentic link, through a 'restorable werelation' (Rose, 1988), to him although she never knew him in person.

Antony has to recreate the world of restorable reach mediated through the mill building: 
I was going there and I was in awe at the size of the place,

I thought it was absolutely magnificent ... this was before I learned of me family's involvement at that mill, which was odd, so I felt attached anyway, I just, there were something about it and that and I love that place ... (Antony's interview)

This fetishisation of the building is more typical of diasporic homecomers than families who stay put (Basu, 2004; Nash, 2003). These forebears have 'reappeared' (Kramer, 2011:392) to Antony in the present through the shared material connection to the place (Jones, 2010). But crucially the 'loss' of his father's generation through the closure of manufacturing industries in the early 1980s and the resulting high unemployment has caused a crisis in reality maintenance (Rose, 1988) leading to a sense of nostalgia and loss. In creating himself as an authentic working class Wiganer through the links to his grandfather and great-grandfather, Antony is also using nostalgic visions of an idealised past to create his place in a shared community memory (Blokland, 2001; Dragojlovic, 2014). 
Ian brought along a paper copy of his family tree and an old map of Wigan to his interview. The family tree covered most of the table in the room. It does not stand alone as a document but needs to be interpreted, by Ian. He underlined how his scientific background gave him a good grounding for all kinds of research. This claiming of his status as a researcher could be a way of claiming authenticity for what he has uncovered and as a sort of performance of being a family researcher (Bottero, 2012; Dicks, 2008, Scodari, 2013). Ian cut out a piece of paper the size of his ancestor's house, scaled according to the map and measured it against the large house where he lives now. The houses in the area where his ancestors lived have all been demolished so the actual material connection is not available as it is for Barbara, but Ian re-established the materiality of the attachment through the use of paper representations. Ian positioned himself as having an authentic working class background with a continuous relation to Wigan, but also as being socially mobile and having moved 'beyond' his past (Bertaux and Delcroix, 2000; Green, 2013).

Nostalgia for a lost community in the past does not necessarily prevent one being an active part of the changed community in the present (Back, 2009; Dicks, 2008; Dragojlovic, 2014). In fact, whilst Barbara and Ian both focus their local history 
activities on remembering, Antony is active in preservation and restoration of the material environment. Through his relations to the buildings, Antony is able to take on responsibility for the past in the present, a way of caring for the place (Hage, 2003: 89). I have argued elsewhere (Bennett, 2014b) that places are 'gifted' from one generation of inhabitants to the next. Here the past, both materially in the form of buildings and in the form of memories, is gifted to the next generation. Hage (2003) explains how symbolic gift exchange is a part of cementing and reproducing community relations and therefore of belonging. Through understanding their relationships to the past of this place Barbara, Ian and Antony are all able to build relationships to the future through passing on knowledge of local history. In this way the minutiae of elements of change in the social world are embedded in an arc of continuity represented through authentic connections to past and present, and it is this sense of continuity that is necessary for a continued belonging (May, 2013: 153; see also Green, 2013).

\section{Belonging and social change}

Each of these family histories exists within the broader context of social change in Britain. The industrial revolution creating the mills, the depression of the 1930s which brought poverty to all these families, the second world war, the welfare 
state improving educational opportunities, the boom of the 1950s and 1960s and the depression of the 1970s and 1980s when Antony's father could not find work, are all present in the narratives.

Barbara connects her own family history to the wider social history of the area through the trope of 'respectable' working class. This is apparent when she talks of her grandfather being 'very, very highly respected' but also through her story of her maternal grandmother who was widowed and left in poverty. She takes pride in the fact that her grandmother could cook potatoes in multiple ways to enable her to survive on a widow's pension. The story of poverty and enduring hardship is emblematic of a respectable working class background. These are not described by Barbara as being exceptional lives but as essentially. The stories create Barbara as an authentic Wiganer - hard working, respectable and originally poor. Family history is largely focussed on individuals rather than representatives of class, gender, race or occupation although there are, as identified in Barbara's narrative, often clear links to a wider social history too (Bertaux and Delcroix, 2000; Bottero, 2012; Dragojlovic, 2014; Green, 2013; Scodari, 2013). 
Antony also positions his family as buffeted by external events. He sees the closure of industries and his father's difficulties in finding work as being due to the policies pursued by Thatcher's Conservative government in the early 1980s. In the past, employment was often found through knowing someone already working in an industry. Antony feels that his grandfather could have secured both his father and himself skilled work, if the mills had continued. In bemoaning the loss of a way of life gone before he was born, Antony's nostalgia is for a particular cultural identity strongly rooted in place and occupation (Nash, 2003; Scodari, 2013).

In focussing on the social mobility in his story, Ian may be playing into his understanding of the sociological remit of this research and the idea of a post-war, 'baby boomer' collective (Dicks, 2008: 444). The story of improvement over time is one that he may have encountered elsewhere and be a particular trope that he is fitting his own story into (Bertaux \& Delcroix, 2000; Scodari, 2013). Social mobility, whilst generally seen as an individual achievement, is also buttressed by society's changes. For Ian the key benefit was the 1944 Education Act which gave him the secondary education his older sister lacked. 
All these different pasts shape present identities. Particularly through the material connections to the place and specific buildings each has the ability to authenticate their identity as a Wiganer (Jones, 2010) using what Smart (2007: 106) refers to as the roots and heritage trope. Through a lack of family connection to the world of restorable reach (Schutz, 1962) Antony provides a nostalgic view of the past in its original sense of a longing for home (Dragojlovic, 2014): he sees himself belonging with his forebears in the working mill, being part of a community of cotton workers. Barbara and Ian, who are both grandparents, use the past to provide continuity within the family story they want to pass on to their descendants. In exploring and remembering the past both in relation to their own family identities and wider community ones, they are all creating a dialogue between the generations (Green, 2013) or linking worlds of restorable and potential reach (Schutz, 1962) in a way which will mitigate change and promote belonging.

\section{Conclusion}

In examining how people negotiate the twin tensions of managing change and continuity in their lives, I have shown tropes of both nostalgia and authenticity 
being used as a point of departure for an active belonging. The unsettling notion of change may induce ontological insecurity; creating an authentic identity through understanding one's connection to the past, can instead create a sense of belonging and ontological security. This also ensures that worlds of reach are kept within reach and stocks of knowledge shared across generations, embedding these individual lives within the wider community over time (Rose, 1988). Change is thus approached gradually, with the family story providing continuity between generations (Green, 2013) and a sense of collective identity through a 'restorable we-relation' (Rose, 1988). Traumatic change and loss with the associated disruptions to individual and community identities is avoided (Dragojlovic, 2014).

Nostalgia is often perceived as a melancholic feeling (Davis, 1979), but here I have shown how it can be a way of demonstrating care for the past. Antony uses his nostalgia for the old cotton mills to connect himself to his family's past and create himself as an authentic Wiganer. Authenticity, seen as embodying what is 'real' or 'true' (Dicks, 2008; Jones and Yarrow, 2013), creates a smooth continuity from the past to the present and future. It represents the backstory, without which we are unsure how to act in the present (Green, 2013; Lawler, 2008). Past and present cannot be examined independently as each constantly 
informs the other (Dicks, 2008; Jones and Yarrow, 2013). Using Schutz's (1962) 'worlds of reach' and 'stocks of knowledge' can help us to understand the relationships across time that we weave into our histories through tropes of nostalgia and authenticity. Through judicious use of these concepts cohesive family and community narratives can be created which cement belonging in the present. Although I have considered these concepts through the life and family history narratives of people whose families have remained in one place for several generations, both nostalgia and authenticity can also be used to tell stories of mobility (see for example Fortier, 2000).

Change is ever-present in social life, as a gradual, humdrum, everyday quality. Human actors in the world tend to focus on continuity (Green, 2013) rather than change which may instigate a sense of ontological insecurity (Back, 2009). Through using both nostalgia, to come to terms with a sense of loss, and authenticity, to create a sense of continuity within an overall arc of change, the stories here have shown how family histories can work to maintain identities over time of both individuals and the communities and places where they belong.

\section{Acknowledgements}


I would like to thank the anonymous reviewers for their insightful comments which have helped to improve this paper.

\section{Funding Acknowledgement}

This work was supported by the Economic and Social Research Council [grant number ES/F022743/1].

\section{References}

Anderson B (2006) Imagined Communities Reflections on the Origin and Spread of Nationalism. London: Verso.

Back L (2009) Researching Community and its Moral Projects. Twenty-First Century Society 4(2): 201-214.

Basu P (2004) My Own Island Home The Orkney Homecoming. Journal of Material Culture 9 (1): 27-42.

Basu P (2007) Highland Homecomings: Genealogy and Heritage-Tourism in the Scottish Diaspora. London: Routledge. 
Bell C and Newby H (1971) Community Studies An introduction to the sociology of the local community. London: George Allen and Unwin Ltd.

Bennett J (2012) Doing Belonging: a sociological study of belonging in place as the outcome of social practices. PhD Thesis, University of Manchester, UK.

Bennett J (2014a) Researching the intangible: a phenomenological study of the everyday practices of belonging. Sociological Research Online 19(1).

Bennett J (2014b) Gifted Places: the inalienable nature of belonging in place. Environment and Planning D Society and Space 32 (4): 658-671.

Bertaux D and Delcroix C (2000) Case histories of families and social processes Enriching sociology. In: Chamberlayne P Bornat J Wengraf T (eds) The Turn to Biographical Methods in Social Science Comparative issues and examples. Abingdon, Oxon: Routledge: pp.71-89. 
Bertaux D and Thompson P (2005) Between Generations Family Models, Myths and Memories. New Brunswick, New Jersey: Transaction Publishers.

Blokland T (2001) Bricks, Mortar, Memories: Neigbourhood and Networks in Collective Acts of Remembering. International Journal of Urban and Regional Research 25(2): 269-283.

Blokland T (2003) Urban Bonds: Social Relationships in an Inner City Neighbourhood. Cambridge: Polity Press.

Bonnett A and Alexander C (2012) Mobile nostalgias: connecting visions of the urban past, present and future amongst ex-residents. Transactions of the Institute of British Geographers 1-12.

Bottero W (2012) Who do you think they were? How family historians make sense of social position and inequality in the past. British Journal of Sociology 63(1): 54-74. 
Bruner J (1991) The Narrative Construction of Reality. Critical Inquiry 18 (1), 121.

Chamberlain M and Thompson P (1998) Introduction. In: Chamberlain M. and Thompson P (eds) Narrative And Genre. London: Routledge: pp. 1-22.

Chase M and Shaw C (1989) The dimensions of nostalgia. In: Shaw C and Chase M (eds) The Imagined Past history and nostalgia. Manchester: Manchester University Press: pp. 1-17.

Crossley N (1996) Intersubjectivity The Fabric of Social Becoming. London: Sage Publications Ltd.

Davis F (1979) Yearning for Yesterday: A Sociology of Nostalgia. New York: Free Press.

Déchaux J-H (2002) Paradoxes of Affiliation in the Contemporary Family. Current Sociology 50(2): 229-242. 
Dicks B (2008) Performing the Hidden Injuries of Class in Coal-Mining Heritage. Sociology 42(3): 436-452.

Dragojlovic A (2014) The Search for Sensuous Geographies of Absence: Indisch Mediation of Loss. Bijdragen tot de Taal-, Land-en volkenkunde (Journal of the Humanities and Social Sciences of Southeast Asia) 170(4): 473-503.

Farrugia D, Smyth J \& Harrison T (2014) Emplacing young people in an Australian rural community: an extraverted sense of place in times of change. Journal of Youth Studies 17(9): 1152-1167.

Favart-Jardon E (2002) Women's `Family Speech': A Trigenerational Study of Family Memory. Current Sociology 50(2): 309-319.

Flick U (2002) An Introduction to Qualitative Research. London: Sage Publications Ltd. 
Fortier A-M (1999) Re-Membering Places and the Performance of Belonging(s).

Theory Culture \& Society 16(2): 41-64.

Fortier A-M (2000) Migrant Belongings: memory, space, identity. Oxford: Berg.

Giddens A (1991) Modernity and Self-Identity:Self and Society in the Late

Modern Age. Cambridge: Polity.

Green A (2013) Intergenerational Family Stories: Private, Parochial,

Pathological? Journal of Family History 38(4), 387-402.

Hage G (2003) Against Paranoid Nationalism: Searching for Hope in a Shrinking Society London: Merlin Press.

Hubble N \& Tew P (2013) Ageing, Narrative and Identity. Basingstoke: Palgrave Macmillan.

Ingold T (1993) The Temporality of the Landscape. World Archaeology 25(2): $152-174$. 
Jones S (2010) Negotiating Authentic Objects and Authentic Selves: Beyond the Deconstruction of Authenticity. Journal of Material Culture: 15(2) 181-203.

Jones S \& Yarrow T (2013) Crafting Authenticity: an ethnography of conservation practice. Journal of Material Culture 18(1), 3-26.

Kramer A.-M (2011) Kinship, Affinity and Connectedness: Exploring the Role of Genealogy in Personal Lives. Sociology 45(3): 379-395.

Kramer A-M (2015) The Genomic Imaginary: Genealogical Heritage And The Shaping of Bioconvergent identities. MediaTropes V(1): 80-104.

Lambert R (1996) The family historian and temporal orientations towards the ancestral past. Time and Society 5(2): 115-43.

Lawler S (2008) Identity Sociological perspectives. Cambridge: Polity Press. 
Lowenthal D (1989) Nostalgia tells it like it wasn't. In Shaw C and Chase M (eds) The Imagined Past history and nostalgia. Manchester: Manchester University Press: pp.18-32.

May V (2013) Connecting Self to Society Belonging in a Changing World. Basingstoke: Palgrave Macmillan.

Nash C (2003) 'They're Family!': Cultural Geographies of Relatedness in Popular Genealogy. In: Ahmed S Castaneda C Fortier A-M Sheller M (eds) Uprootings/Regroundings Questions of Home and Migration Oxford : Berg: pp.179-203.

Nash C (2004) Genetic kinship. Cultural Studies 18 (1): 1-33.

Nash C (2005) Geographies of Relatedness. Transactions of the Institute of British Geographers, New Series 30 (4): 449-462.

Richardson L (1990) Narrative and Sociology. Journal of Contemporary Ethnography 19 (1), 116-135. 
Robertson D, Smyth J and McIntosh I (2008) Neighbourhood Identity: People, Time and Place. Report, Joseph Rowntree Foundation, York.

Rose C (1988) The Concept of Reach and the Anglophone Minority in Quebec. In: Eyles J and Smith DM (eds) Qualitative Methods in Human Geography Cambridge: Polity Press, pp. 156-179.

Savage M (2005) Working-Class Identities in the 1960s: Revisiting the Affluent Worker Study. Sociology 39(5): 929- 46.

Savage M (2008) Histories, Belongings, Communities. International Journal of Social Research Methodology 11(2): 151-162.

Savage M, Bagnall G and Longhurst B (2005) Globalization and Belonging. London: Sage.

Schutz A (1962) Collected Papers I The Problem of Social Reality. The Hague: Martinus Nijhoff Publishers. 
Scodari C (2013) Roots, Representation, and Resistance? Family History Media \& Culture through a Critical Lens. The Journal of American Culture 36(3), 206-220.

Smart C (2007) Personal Life New directions in sociological thinking.

Cambridge: Polity Press.

Strathern M (1992) After Nature English kinship in the late twentieth century. Cambridge: Cambridge University Press.

Taylor S and Littleton K (2006) Biographies in talk: A narrative-discursive research approach. Qualitative Sociology Review 2(1): 22-38.

Thompson P (2000) The Voice of the Past Oral History (3rd ed.). Oxford: Oxford University Press.

Wright P (1985) On Living in an Old Country The National Past in Contemporary Britain. London: Verso. 
Zerubavel E (2012) Ancestors and Relatives: Genealogy, Identity and Community.

Oxford: Oxford University Press. 